\title{
ADAPTATION OF THE CZECH REPUBLIC DEFENCE POLICY LESSONS LEARNED
}

\author{
Ing. Josef PROCHÁZKA PhD
}

University of Defence, Brno, Czech Republic

The choices we make today can mean greater security and prosperity for our Nation for decades to come.

President of the United States of America in National

|Security Strategy 2015

\begin{abstract}
Since the end of 1989 defence policy of the Czechoslovakia and after its dissolution in 1993 defence policy of the Czech Republic has been permanently adapted to the challenges of the new political reality and evolving strategic environment. Political reality reflected the revolutionary shift in political system aiming at the development of modern democratic state. Challenges coming out from the strategic environment could be characterised by its growing dynamics, complexity, unpredictability and uncertainty. This article highlights some of the remarkable achievements in this two and half decade lasting transitional endeavours and underscores some of the most important lessons learned related to defence policy formulation, defence strategy implementation, defence planning, defence resource management and acquisition.
\end{abstract}

Key words: Defence policy, defence strategy, defence planning, defence resource management, acquisition 


\section{Introduction}

The Czechoslovak's military in November 1989 was completely different sort of organisation as we can witness today. It was an instrument serving entirely to the purpose of totalitarian regime dominated by one ruling political party. ${ }^{1}$ It was build and prepared to fulfil grand strategy with predominantly offensive objectives of potential superpowers' conflict accompanied most likely with a massive employment of nuclear weapons.

Robust military potential ${ }^{2}$ was kept in a high readiness mode supported by building-up plans in order to mobilize all state resources in case of war both in terms of personnel and materiel. Trends of main weapon system are depicted in Table 1 (see below).

In addition to that also state owned economy was organised in the way which would allow sustaining the war time military structure operating under operational concept of high intensity military confrontation.

From this perspective, it was a complex task for new political leadership and military senior representatives after 1989 to ensure that the new style of military organization is created and in the same time it will be fit for purpose under the new political circumstances and in different strategic context.

Without any doubts, remarkable progress has been achieved in two and half decades of permanent process of defence policy adaptation. Despite several ways of reorganization the Czech Republic Armed Forces (CAF) have always been able to contribute to Euro-Atlantic peace and stability. In a meanwhile, the Czech Republic has turned from the security consumer to the security contributor. It offers forces to the multinational crisis management around the Globe.

Nevertheless, we have to be frank. Mistakes were inevitably made taking in consideration the complexity of this transition goal. A significant portion of

$182 \%$ of professional soldiers were members of the Communist Party.

2 In 1989 the personnel strength of Czechoslovak Armed Forces was 120 thousand military and 80 thousand civilians. 
lessons have already been learned and the remaining should be learned in the future.

All these achievements and related mistakes in the transformation from a totalitarian military to the military of a democratic country provides a significant source of information for further research, generalisation and conceptualisation. Outcome of this research might help politicians, commanders, strategic planners and scholars to be more effective when dealing with a similar or the same kind of scenario again.

\begin{tabular}{|c|c|c|c|c|c|}
\hline & $\begin{array}{l}\text { Main Battle } \\
\text { Tanks MBT } \\
\end{array}$ & $\begin{array}{l}\text { Armed Combat } \\
\text { Vehicles ACV }\end{array}$ & $\begin{array}{l}\text { Artillery } \\
\text { Systems AS }\end{array}$ & $\begin{array}{l}\text { Combat } \\
\text { Aircrafts CA }\end{array}$ & $\begin{array}{l}\text { Attack } \\
\text { Helicopters AH }\end{array}$ \\
\hline 1991 & 3315 & 4593 & 3485 & 446 & 56 \\
\hline 1993 & 1617 & 2315 & 1516 & 227 & 34 \\
\hline 1995 & 1011 & 1451 & 893 & 215 & 36 \\
\hline 1997 & 952 & 1367 & 767 & 143 & 36 \\
\hline 1999 & 938 & 1219 & 754 & 114 & 34 \\
\hline 2001 & 652 & 1211 & 648 & 97 & 34 \\
\hline 2003 & 541 & 1235 & 528 & 125 & 34 \\
\hline 2005 & 298 & 747 & 362 & 103 & 32 \\
\hline 2007 & 181 & 580 & 321 & 38 & 38 \\
\hline 2009 & 178 & 490 & 259 & 42 & 29 \\
\hline 2011 & 166 & 494 & 244 & 38 & 25 \\
\hline 2013 & 123 & 501 & 182 & 39 & 24 \\
\hline 2015 & 123 & 442 & 179 & 39 & 17 \\
\hline $\begin{array}{l}\text { CFET } \\
\text { Ceilings }\end{array}$ & 957 & 1367 & 767 & 230 & 50 \\
\hline
\end{tabular}

Source: The Czech Republic MoD. Available at: http://www.mocr.army.cz/

Remarks: The figures in 1991 are related to the Czechoslovak Armed Forces.

Table 1. Number of major weapon and equipment systems 1993-2015

\section{Defence Policy}

Formulation of defence policy objectives in the post-revolution time was influenced by changes of political, legal, security, economic and social system. 
Defence policy main objective immediately after the Velvet Revolution at the end of the year 1989 was to establish civil oversight and democratic control of the military in order to mitigate any risk of misusing the enormous military potential against the society democratisation process. In this regard it was successful, because this situation did not happen. Already in course of 1990 the basic new legislation was adopted by the democratically elected Parliament applying approaches proved in western democracies. The created legislation framework that instituted relationship among executive, legislature and judicial authorities was promptly implemented. The political apparatus in the military structures was abolished and senior military leadership had to leave their positions already at the end of 1989. Some of by the Communists formerly persecuted officers returned to the regular military service once again and balanced the old and new military culture.

However, even the new legislation did not prove fully functional when not run and staffed by experts possessing necessary knowledge and experience. Throughout more than two decades the political and senior military leadership maturity with regard to defence management has been identify as a one of the main limitation factor in the process of defence policy formulation and its successful implementation. Traditionally, civil-military relations have been about keeping the military out of politics. In the Czech Republic of the 1990s, however, the problem was the other way around: how to persuade politicians to take an interest in defence. ${ }^{3}$ Since 1989 there were 19 defence ministers assuming their political responsibility and 6 Chiefs of Defence Staff.

Therefore, the current state of the Czech Armed Forces (CAF) is an outcome of along-terminsufficientresourcingina combination of notwell informed managerial decisions. Those decisions are related for example to the implementation of disputable modernisation programs and controversial structural changes applied across whole defence sector. One factor of that outcome is that the politico military advice was not heard properly during the decision making.

3 Šedivý J., Analysis Czech military transformation. NATO Review. Spring 2015. Available from: http://www.nato.int/docu/review/2005/issue1/english/analysis.html 
Furthermore, military budget was very often seen as the reserve fund for government spending ${ }^{4}$ in case of austerity or state of emergency (for example floods in 1997 and 2002 or economic austerity in 1997 and 2009 and beyond). Economic transformation has always yield a priority for political leadership. Only shortly before and immediately after the Czech Republic joined NATO in March 1999 defence budget enjoyed required political attention and defence spending attacked the NATO bench mark of $2 \%$ of GDP. Trends in defence budget are depicted in Chart 1 (see below).

The second most important objective of the Czech Republic defence policy after the fall of Iron Curtain and the end of high probable blocks military confrontation was to reform and restructure massive armed forces which were deemed unnecessary in changed security environment and financially unsustainable considering the pessimistic economical perspective of the country. Subsequent downsizing and eventual professionalization were seen as the most logical next step. ${ }^{5}$ The speed of structural reforms was the main success factor. Unfortunately, it was not the case of the Czech Republic. Gradual and too prudent approach to change management was picked up. It resulted in waves of unpopular reforms in $90^{\prime}$ and at the beginning of the new millennium, high level of uncertainty, instability and significant loss of staff motivation.

Fast pattern of reforms was seen as too risky from the social perspective with the potential for destabilising existing status quo in the society. No wonder that many capable young officers some of them already educated in western military schools were disappointed by this situation and frustrated by lack of vision they would consider worthy for participation in its implementation. The political leadership and commanders were unable to offer the military personnel required opportunities for their career development. Officers have been living service and created a significant gap in military skills across the command and control domain - brain function has been gradually diminishing.

4 Šedivý J., Analysis Czech military transformation. NATO Review. Spring 2015. Available from: http://www.nato.int/docu/review/2005/issue1/english/analysis.html

5 Treaty on Conventinal Armed Forces in Europe was implemented and a new term was coined in the political vocabulery in the 90' - defence sufficiency. 
In addition to the peril of strategic culture and strategic thinking, the command and force structure have carried an enormous burden of very unhealthy tail to head ratio living only limited space for investments in muscles (front line capabilities). Too much of scarce resources have been misallocated in order to operate and maintain obsolete equipment and aging military infrastructure. Abandonment of any particular garrison, airfield and any kind of military installation was subject to compromised political decisions trading of a military requirement and a social impact (job opportunities, prosperity of local companies).

The third objective of defence policy was associated with the restructuring and conversion of the arms industrial base that suffered a very quick decline in both domestic and foreign markets and the overall radical downturn in demand for arms. Due to the application of idealistic politics exercised by the former President Vaclav Havel most of the defence industry traditional capabilities were irreversibly lost. Some of the companies were successfully privatised and transformed in dual use or civil production. Most of them simply disappeared from the market. Only few companies regarded as a strategically important for defence remained in the state ownership. It was fund to challenging for many of defence industries to switch to the free market economy and in the same time to adjust their strategies to the new realities. Main factor was instability. There were no clear and realistic plans and long term modernisation programs in the MoD which would orient the research, development and production of weakened and aging defence industry and offer reasonable amount of perspective for its prosperous long - term development.

Since 1989 the defence policy was depicted in nearly 25 different sort of strategic and conceptual documents stipulating visions, strategies and objectives. However, most of them have never been implemented or were implemented only partially due to the fact that immediately after the government adaptation there was a gap between deliberations and resources and that there was almost no continuity after government change. 


\section{Defence Strategy}

A range of alternative approaches were considered to ensure national defence after 1989, including potential neutrality. A higher premium was placed on seeking international guarantees while maintaining credible level of own defence capabilities. This requirement was driven by limited national resources for provision of a credible defence posture. ${ }^{6}$

After the Warsaw Treaty ceased to exist and the Soviet troops withdraw from the state territory in June 1991 there was finally a room for manoeuvre to develop an independent defence strategy. The basic strategic assumption at this point in time was that there is not an imminent threat to the state sovereignty and its territorial integrity. Defence strategy reflected the need to defend country individually from all possible directions against no identified opponent. The military posture reflected this fact. Troops were distributed equally on the state territory and the cold war western orientation of military power disappeared for ever. Principal of reasonable sufficiency was adopted.

With the NATO membership the defence strategy of the Czech Republic was built on positive developments in the strategic environment and the fact that large-scale conventional aggression against the Alliance and the Czech Republic is highly unlikely. Nevertheless, the possibility of such a threat emerging over the longer term exists. ${ }^{7}$ Defence of Czech Republic was not related exclusively to its own territory but also to the persuasion of its security interests abroad. Preserving stability and security in regions of interest through NATO and EU-led operations or coalition operations was seen as the most effective way of minimizing negative effects to security interests of the Czech Republic and her allies. ${ }^{8}$

As a result of this strategy deployability and sustainability of the CAF was enhanced. Development of the CAF aimed at providing usable and beneficial capabilities for

6 Armed Forces of the Czech Republic, A Symbol of Democracy and State Sovereignity 1993 - 2012. MOD of the Czech Republic, 2013. ISBN 978-80-7278-601-5.

7 The Alliance Strategic Concept, Approved by the Head of State and Government participating in the meeting of the North Atlantic Council in Washington D.C. on 23 and 24 April 1999.

8 The Military Strategy of the Czech Republic, Prague 2008. 
multinational task forces. The CAF was not supposed to possess the full spectrum of capabilities that would be otherwise necessary for autonomous defence and operations. The most important strategic assumption was that there will be so called a reaction time for overall reinforcement of defence sector functioning based on an early warning intelligent capability to asses and predict the worsening of security environment in credible way and timely manner.

Meanwhile, the inter-state conflict in Europe is back at the agenda by Russia's violation of Ukraine's sovereignty and territorial integrity - as well as its belligerent stance towards other neighbouring countries. This situation calls for reassessment of strategic assumptions and outlining a new defence strategy of the Czech Republic. We need to adopt a strategy which will be predominantly security driven instead of purely resource guided and put more emphasis on development of balanced set of capabilities relevant for coping also with less probable kind of scenarios. We do not possess the comfort of any reaction time to prepare for defence of Euro-Atlantic civilisation together with our Allies when the first symptoms of crises are indicated. We need to be ready for this task already now.

\section{Defence Planning}

Planning become almost a dirty word after the Central Communist Planning was abolished. Planning was offset by short term budget preparation and execution. But, this approach contradicted the nature of defence sector functioning. Forward looking, effective and efficient development of military capabilities requires at least middle term planning horizon which will orient research, acquisition of military equipment and preparation of personnel.

Furthermore, not one of the many national security strategies adopted by governments provided an unambiguous and clearly focused set of guidelines that could be then operationalised as military strategy and doctrine, and implemented in terms of command- and force- structure development. ${ }^{9}$

9 Šedivý J., Analysis Czech military transformation. NATO Review. Spring 2015. Available at: http://www.nato.int/docu/review/2005/issue1/english/analysis.html 
Some shift in the approach to the defence planning came with the NATO membership. New defence planning system at the national level was established. The State Security Cancel was established in 1999 with the responsibility for strategic level defence and security matters coordination. Defence legislation was overhauled setting in practises necessary processes for defence planning at the national level involving not only the military but also relevant ministries, agencies and private sector. Defence of the country became a responsibility of all citizens. This approach was doctrinalised by the Czech Republic Defence Strategy 2011.

Within the MoD many attempts was undergone in order to establish modern defence planning system dealing with a holistic approach to capability development reflecting all functional areas (doctrines, organisation, training, leaderships, material, personnel, facilities and interoperability). Furthermore, it was an imperative to harmonised defence and resource planning and acquisition, and institutionalise short-, middle- and long-term planning horizon. Up to now the outcome of long - term planning process is still missing causing remarkable gab in defence planning effectiveness.

In recent years more emphasis was put on the output rather than input, as a result of that an objective based planning and budgeting was introduced. This approach is completely valid, however, it struggles with enormous administrative burden and limited ability of defence planners to set up measurable and manageable objectives across the defence organization.

Adjustment of defence planning system and related business processes will continue in order to develop backbone instrument for the development of defence sector spanning Armed Forces, MoD, other ministries, public administration and private sector and which will be complementary to NATO and EU defence planning processes.

\section{Defence Resource Management}

One of the main weaknesses in defence management was the insufficient integration of all the three resource pillars - material, finance and personnel. In terms of material there was unfortunately no life cycle approach implemented resulting in lower buying price but much higher in-service support costs. 
Human resource management was unable to introduce an forceable rules for a centrally controlled, transparent, competitive and selective professional career, and apply objective criteria for evaluating soldiers' performance. In the $90^{\prime}$ there was not a system at all causing unhealthy and unaffordable personnel structure (to many high ranking officers and insufficient numbers of lower rank as a heritage of the soviet era). With the introduction of fully professional Armed Forces there was a need to recruit people on the competitive free market influenced by negative demographic trends (aging population, decreasing fitness and health condition of young population). Because of that the military service was open also for women. ${ }^{10}$ The need for raising the attractiveness of the military profession and competitive strength in the labour market still persists. ${ }^{11}$ Trends of personnel strange see the charter 2 .

Officially stipulated objective to motivate and prepare competent personnel has never been properly implemented and it remains also a significant risk for the future. There is a need to develop new organisational culture and change the mind set of young military professionals who must be proud, selfconfident, knowledgeable, prepared to lead in multinational and complex environment and assume responsibility. To make it a reality also military education system must be enhanced and should put more emphasis on military aspects of education and moral qualities.

Budgeting system has enjoyed too much importance. Instead of being a supportive function responsible for budget preparation and execution. It assumed also responsibility for short term planning, setting rules and making decision in case of reallocation of financial resources and prioritisation of requirements when budget was cut. There was a lack of transparency and accountability in all related business processes. Budgeting function did not provide required outputs for effective day to day management. Most of the budget has been spent in the last two months of each fiscal year. Enormous problem was to spend all money allocated for defence purposes during one fiscal year. Reserves fund accumulating lapsed credits for investment programmes was the first portion of money taking by the government in time of austerity.

10 In 1998 there was more than $12 \%$ of woman serving in uniforms.

11 The White Paper on Defence 2011, Ministry of Defence, Prague 2011. Available at: http://www.army.cz/ministry-of-defence/newsroom/news/the-white-paper-on-defence2011--63155/. 
However, shrinking budgets put more importance on effectives and efficiency. New impetus came with the implementation of private sector best practises - output rather than input way of thinking. Nevertheless, performance measurement has not been working properly, yet. Objectives are lacking realistic and reasonable key performance indicators and accounting is unable to provide feedback on exact cost for activities.

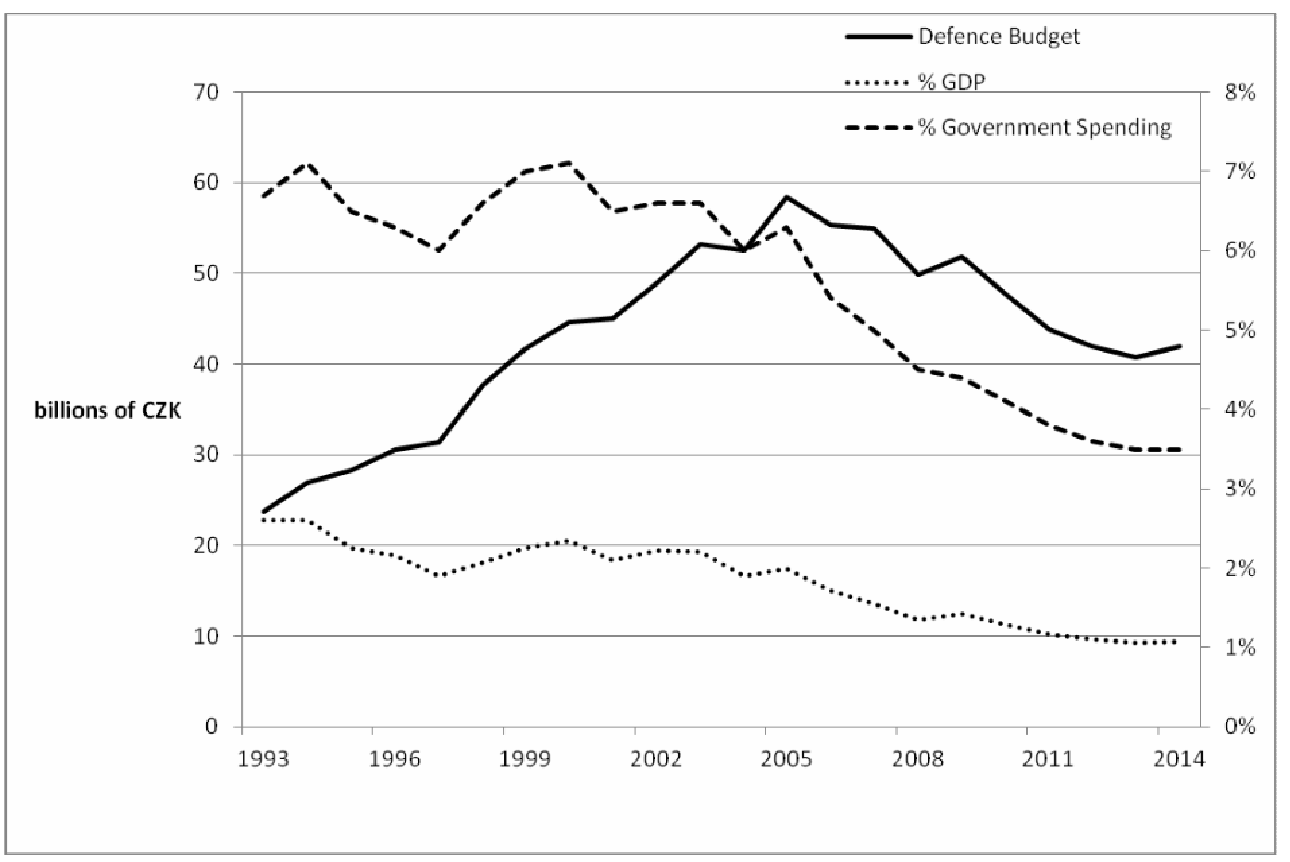

Source: The Czech Republic MoD. Available at: http://www.mocr.army.cz/

Chart 1. Trends of The Czech Republic Defence Budget 1993-2015

\section{Acquisition}

Is acquisition really the main weakness in defence management or it is just a huge amount of frustration? Acquisition function was a victim of political pressure and customer disappointment. One can't have an effective acquisition system if doesn't deliver proper planning outputs in timely manner (rather functional specification of required capability than uncompleted description of required products replacing existing platforms). 
Precondition is that you deal with a smart customer able to stipulate operational requirements and that there exist a competitive and technologically advanced market to satisfy your needs. And in addition to that politicians must provide the acquisition process with a legislative framework allowing program and project managers to do their job with required level of trust and freedom of action. Nothing of that mentioned above has been in place for the entire period since 1989. Reforms aimed once at centralisation and secondly at decentralisation of this function have been implementing with almost invisible outcome in the performance.

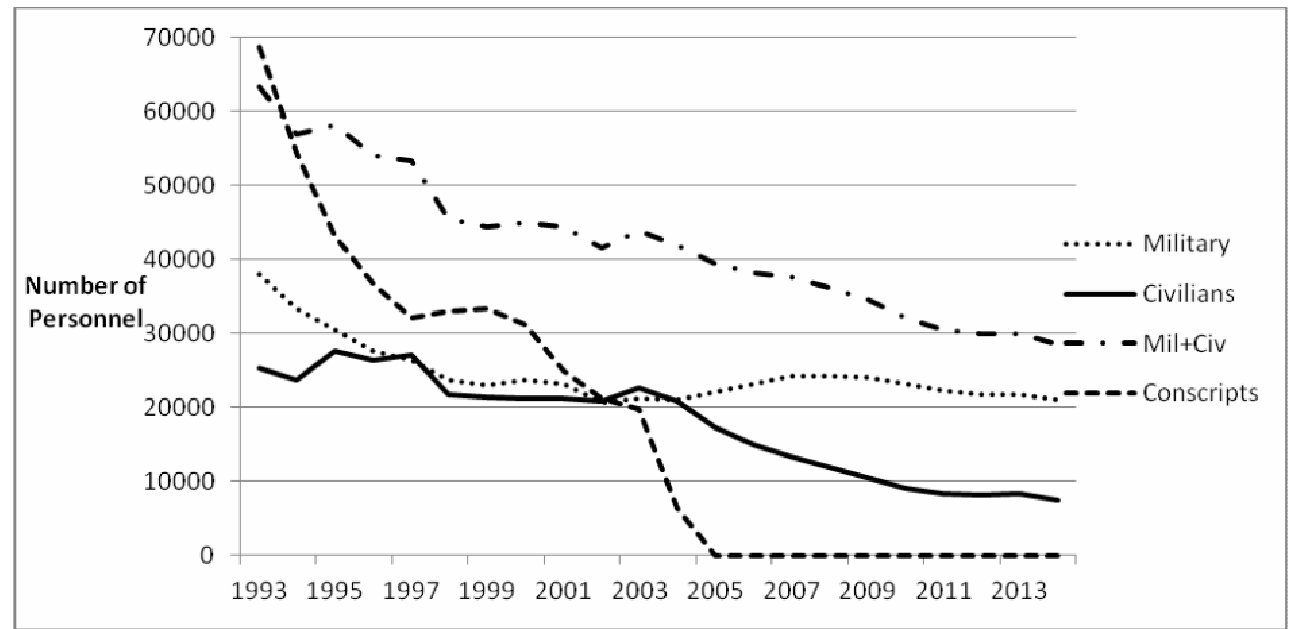

Source: The Czech Republic MoD. Available at: http://www.mocr.army.cz/.

Chart 2 Trends of The Czech's Armed Forces Personnel Strange 1993-2015

Decisions on most of the main acquisition programs in 90's did not reflect properly the pattern of reforms and long - term operational needs. Programs were a result of disputable and controversial decisions both in military and political domain. In the new millennium the modernisation of Armed Forces addressed mostly the urgent operational requirements from operational deployments overwhelmingly from Afghanistan (afghanisation). Lessons here is obvious: armed forces modernisation must by an outcome of long term considerations, balancing top-down and bottom - up approach and reflecting social, economic and technological aspects. 


\section{Conclusion}

Despite all the above mentioned constrains the CAF have been able to adapt to the challenges of internal and external environment and political realities. The CAF has turned in an effective instrument of country's security and defence policy and enjoyed public recognition for its activities. Indeed, the Czech Republic is often presented as a role model for other countries seeking to transform their own defence sector. More than 15 thousand of military personnel have been successfully deployed in multinational operations. The Czech Republic is not just a consumer but also a security contributor sharing fair burden of collective defence. The concept of full- professional armed forces is also functioning relatively well.

Yet everything is not always as it seems. The big issue today is to ensure that command and force structure is properly staffed, equipped and trained and that the CAF remain relevant in terms of operational effectiveness, timely availability and financial sustainability in middle and long term perspective.

Defence policy formulation and implementation was hampered by limited political interest (with exception of the time the Czech Republic joined NATO). Furthermore, there was significant personnel instability on senior political and military positions resulting in limited maturity of decision makers. Unfortunately, there was now agreement across the political spectrum on main building blogs of our defence policy orientation and its resourcing. Outcome of this was instability!!

Defence strategy was mainly adjusted to ever declining defence resources. Resource driven strategy was adopted! Resource scarcity impacted negatively all areas of defence sector. Debt on people, equipment and infrastructure has grown and in the combination with high operational tempo in deployed operations, it will be difficult to mitigate (long term goal).

Defence planning was hampered by general rejection of long-term planning, which was perceived as associated with the previous regime and allegedly incompatible with market economy. Currently, defence planning process provides relatively modern framework for setting political objectives, defining minimum capability requirements and allocating resources in short and middle term outlook. 
Last but not least, structures and business processes within the MoD have been streamlined many times. However, reforms did not get adequate time to work and generate effectiveness and efficiency. Resource management and acquisition processes are too heavy, not harmonised and centralised properly. There are also lacking necessary expertise, institutional memory and performance oriented culture. It might be improved in middle term perspective.

\section{References}

The White Paper of Defence was approved by the Governmental Resolution of 18th May 2011, Nr. 369.

National Security Strategy of the United States of America, February 2015. Available at: http://nssarchive.us/wp-content/uploads/2015/02/2015.pdf.

PROCHÁZKA J., Twenty Years of the Army of the Czech Republic: How to go on. Vojenské rozhledy, 2013, roč. 22 (54), č. 2, s. 48-58, ISSN 1210-3292 Available at: http://www. vojenskerozhledy.cz/kategorie/download/340_8e81e5f397c393376df560d07c75e179.

JANOŠEC, J., PROCHÁZKA, J., TƯMA, M. Obranná politika Československé a České republiky (1989-2009). MO ČR-PIC MO, 2009. ISBN 978-80-7278. Available at: http://www.mocr.army.cz/assets/multimedia-a-knihovna/publikace/bezpecnostnitemata/23-obranna-politika-ceskoslovenske-a-ceske-republiky-1989_2009.pdf. 